\title{
Autoritarizmas Baltarusijoje: galimos grèsmès Lietuvos saugumui
}

\begin{abstract}
Baltarusija yra labiausiai autoritariška valstybė Vidurio ir Rytu Europoje. Aleksandro Lukašenkos režimo keliamas grèsmes tarptautinè saugumo bendrija identifikuoja globaliniame ir regioniniame lygmenyse. Straipsnyje analizuojama problema: kokias konkrečias grèsmes Lietuvai kelia baltarusiškas autoritarizmas? Pateikiami šios problemos pjūviai - autoritarizmo Baltarusijoje kilmé, priklausomybès modelis Baltarusijos-Rusijos santykiuose, tarptautinè saugumo bendrija ir Baltarusija, Lietuvos-Baltarusijos santykių raida - leidžia konkretizuoti galimas Lietuvai grésmes pagal politinị, karinį, socialini, ekonominį, ekologinị sektorius.
\end{abstract}

Po Baltarusijos Respublikos pripažinimo nepriklausoma valstybe jos ir euroatlantinès bendruomenès ryšiai plètojosi pakankamai dinamiškai. Baltarusijai buvo suteiktas asocijuoto nario NATO Parlamentinèje Asamblejoje statusas. 1995 m. tarp Baltarusijos ir Europos Sajungos buvo pasirašytas Partnerystės ir bendradarbiavimo susitarimas.

Tačiau 1996-1997 m. tarptautinės saugumo bendruomenès santykiai su Minsku atšalo, kadangi prezidentas Aleksandras Lukašenka valstybės vairą aiškiai pasuko autoritarizmo linkme (1996 m. surengtas vadinamasis konstitucinis referendumas pakeite politinio proceso taisykles: buvo paleista 13-ojo šaukimo Aukščiausioji taryba, panaikinta $1994 \mathrm{~m}$. Konstitucija, pratęsta prezidento kadencija, griebtasi represinių priemonių prieš politinius oponentus, falsifikuojami rinkimai ir t.t.).

Trumpiau tariant, Baltarusija tapo savotiška išimtimi Vidurio ir Vidurio Rytų Europoje. Tuo metu, kai kaimyninėse šalyse konsoliduojama demokratija ir siekiama narystės euroatlantinėje erdvėje, Rusija skelbia provakarietiškos užsienio politikos erą, kartu su Šiaurès Atlanto sutarties organizacija imasi bendradarbiauti NATORusijos Taryboje, yra pripažįstama rinkos ekonomikos šalimi ir net Ukraina bando aiškiau išsakyti savo siekį ateityje tapti NATO nare, Baltarusijoje vyksta visiškai priešingi procesai.

Vos kelios dienos prieš rugsèjo 11-osios teroristų išpuolius Jungtinių Valstijų valstybės sekretorius Collin Powell diktatūrinę valstybę Baltarusiją pavadino „vienintele Europos šalimi, esančią už įstatymo ribų“1 . Tuo metu amerikiečių diplomatijos vadovas akcentavo pačio autoritarinio režimo, jo prigimtyje slypinčių grèsmių pavojų regioniniam saugumui apskritai.

\footnotetext{
"Prof., dr. Raimundas Lopata - humanitarinių mokslų daktaras, Vilniaus universiteto Tarptautiniu santykių ir politikos mokslų instituto direktorius. Adresas: Vokiečių 10, 2001 Vilnius, tel. 8-52514130, e-paštas: raimundas.lopata@tspmi.vu.lt

${ }^{1}$ M. Lenzi Iš Minsko eina tamsūs ginklų keliai, Lietuvos Rytas, 2002 m. birželio 1 d. Nr. 125.
} 
Visų pirma buvo apeliuojama ị prie Baltarusijos Vidaus reikalų ministerijos įkurtą sukarintą grupę, kuriai buvo pavesta vykdyti bet kokias užduotis, taip pat ir politines žmogžudystes ${ }^{2}$. Nebuvo pamirštas ir Lukašenkos įsakas, kuriuo remiantis be teismo galèjo būti konfiskuojamas gyventojų ir įmonių turtas. Beje, šiuo ịsaku bei politiniu šantažu ir įbauginimo metodais ypač naudotasi tuoj po $2001 \mathrm{~m}$. rugsẻjo prezidento rinkimų, kuomet buvo suimti devyni baltarusių įmonių vadovai ${ }^{3}$, o taip pat be skrupulų prieš opozicijos renginius buvo reguliariai naudojamos jẻgos struktūros.

Pabrèžtina, kad tarptautinès saugumo bendrijos nerimą kẻlè ne tik precedentų neturintys žmogaus teisių pažeidinėjimai Baltarusijoje. Regioninio saugumo kontekste ypač kreipiamas dèmesys į dar kelias aplinkybes.

Pirmoji - Baltarusijos karinė galia, kuri yra žymiai didesnė už, pavyzdžiui, kaimyninių Lietuvos ir Latvijos.

Antroji - atviri paties Lukašenkos pasisakymai ir veiksmai tarptautinèje arenoje. Čia turima galvoje ne tik aršios ir dažnai įžeidžiančios baltarusių prezidento kalbos prieš Vakarus, ar vizitu grafikas - Kuba, Sirija, Libija ${ }^{4}$, bet ir provokaciniai kariniai manevrai. Pavyzdžiui, prieš pat prezidento rinkimus $2001 \mathrm{~m}$. rugsèji vykusiose karinèse pratybose „Neman-2001“ baltarusiai imitavo lietuvių ir lenkų puolimo atrėmimą, o $2002 \mathrm{~m}$. vasaros pradžioje „Berezina-2002“ pratybos imitavo Berezinos upės forsavimą ir puolimą Vakarų kryptimi.

Trečioji - tai katastrofiškai blogejanti ekonominė situacija ir iš esmés visiško ekonominio žlugimo grèsmè.

Štai tik keli momentai, leidę ne tik teigti apie Baltarusiją kaip šali, esančią už istatymo ribų, bet ir detalizuoti galimas pasekmes regioniniam saugumui-neprognozuojamas režimas, spontaniška politika, destabilizuota ekonomika ir galimi pabėgèliai.

Tačiau pastaruoju metu šio teiginio prasmè tampa dar akivaizdesnè. Paskutinis autoritarizmo bastionas Europoje, valdomas Lukašenkos režimo, ir toliau pažeidinejja tarptautinę teisę. Minskas per praejusius metus tyliai tapo pagrindine karinès ginkluotės tiekèja Irakui ${ }^{5}$, kitoms karingoms valstybėms bei teroristų grupuotėms tiekė aukštos kokybės karinę ịrangą. Ir pagaliau - taip pat pastaruoju metu ypač išryškejjęs visiškas oficialaus Minsko nesiskaitymas su tarptautinèmis organizacijomis (iš esmès paralyžiuota Europos saugumo ir bendradarbiavimo organizacijos misija Baltarusijoje).

\footnotetext{
${ }^{2}$ Apie tai viešai pareiške buvę Baltarusijos prokuratūros tardytojai Olegas Slučekas ir Dmitrijus Petruškevičius, pasiprašę politinio prieglobsčio JAV. Jų duomenimis, minètos grupès aukomis tapo politikai Jurijus Zacharenka, Viktoras Gončaras, Anatolijus Krasovskis, žurnalistas Dmitrijus Zavadskis. Pl. žr.: Vadovas giriasi abejotinais nuopelnais, Lietuvos Rytas, 2001 m. lapkričio 19 d. ${ }^{3} 2001 \mathrm{~m}$. rudeni - $2002 \mathrm{~m}$. pradžioje buvo suimti: Minsko šaldytuvu gamybos susivienijimo „Atlant“ direktorius Leonidas Kaluginas, Baltarusijos geležinkelių vadovas Viktoras Rachmankovas ir jo pavaduotojas Jevgenijus Nazarenka, Minsko stadiono „Traktor“ direktorius Vladimiras Oleinikovas, automobilių turgaus „Kolco“ direktorius Aleksandras Vasilevskis, Minsko traktorių gamyklos generalinis direktorius Michailas Leonovas, Gomelio radijo gamyklos direktorius Anatolijus Kirikovas ir kt. Pl. žr.: Baltarusijoje - nauja suėmimų banga, Lietuvos Rytas, 2001m. lapkričio 24 d.; Baltarusijos ịmonių vadovų persekiojimas - kerštas už rinkimus, Lietuvos Rytas, $2002 \mathrm{~m}$. sausio $11 \mathrm{~d}$.

${ }^{4}$ Ir vice versus - pavyzdžiui, $2002 \mathrm{~m}$. sausio pradžioje Lukašenka pakviete Muamarą al Gadafi, o vasarị - Irano prezidentą Mohamedą Katami atvykti oficialaus vizito ị Minską. Žr.: BNS pranešimai, $2002 \mathrm{~m}$. sausio $18 \mathrm{~d}$. ir vasario $14 \mathrm{~d}$.

${ }^{5}$ Apie Baltarusijos ir Irako santykius atvirai prabilta ir Lietuvoje. Žr.: Seimo narys ragina daugiau aiškinti Baltarusijos gyventojams apie demokratiją, $B N S, 2002 \mathrm{~m}$. spalio $2 \mathrm{~d}$.
} 
Taigi akivaizdu, jog tarptautinė saugumo bendruomene įžvelgia potencialias Baltarusijos keliamas grèsmes tiek globaliame, tiek regioniniame lygmenyje. Problema-kokios tikètinos besiklostančios situacijos Baltarusijoje ir aplink ją pasekmès Lietuvai ir jos saugumui?

Ieškant atsakymo ir identifikuojant galimas grèsmes pagal sektorius (politinis, karinis, socialinis, ekonominis, ekologinis ${ }^{6}$ ) plačiau yra analizuojami šie problemos aspektai:

- Baltarusiško autoritarizmo kilmė ir galima jo specifikacija.

- Baltarusijos-Rusijos santykiai: priklausomybès modelis teorijoje ir praktikoje.

- Tarptautinè saugumo bendrija ir Baltarusija.

- Lietuvos-Baltarusijos santykių dinamika.

\section{Baltarusiškojo autoritarizmo kilmè ir galima jo specifikacija}

Šių dienų Baltarusija išties užminè painų galvosūkị: kodèl pasirinkta būtent tokia raida ir kokie gali būti tolesni šio režimo transformavimosi variantai?

Teoriniuose darbuose, skirtuose visuomenių transformacijų ir demokratizacijos procesams, paprastai yra išskiriami aiškūs kriterijai, be kurių vienos ar kitos visuomenès evoliucija į demokratinę visuomenę yra negalima:

- pakankama ekonominè pažanga;

- tarptautinè aplinka (kuo nuosekliau šalis orientuojasi į vakarietiškos civilizacijos vertybes, tuo didesnè tikimybė demokratijos progresui);

- politinès tradicijos (egzistuoja demokratinè tradicija, ar ne?);

- institucinès struktūros (parlamentarizmas, prezidentinè sistema ir pan.) ${ }^{7}$.

Vargu ar reikia daug aiškinti, jog nei vienas iš aukščiau minètų kriterijų „neveikia“ Baltarusijoje. Ją iš kitų pokomunistinių šalių išskiria tai, kad ir žlugus komunistiniam režimui politiniai bei ekonominiai svertai liko tų pačių politinių jègų rankose. Valdantysis elitas ne tik išliko, bet ir nebuvo priverstas pasikeisti.

Po 1991 m. rugpjūčio pučo Maskvoje Baltarusijos nomenklatūra buvo priversta sekti Rusijos ekonomikos reformų pédomis, bet šie pertvarkymai buvo vykdomi tik iš dalies. Buvo liberalizuotos kainos, tačiau nebuvo imtasi griežtos pinigų politikos ir privatizavimo. Kad nebuvo vykdomas privatizavimas, lėmé valdančiojo elito siekis išlaikyti valstybinę nuosavybę, nes konkurencijos sąlygomis jų įmonès būtų žlugusios. Pusinès ekonomikos reformos neigiamai atsiliepè didesniajai šalies gyventojų daliai, tačiau jos atitiko nomenklatūros interesus ${ }^{8}$.

Ekonomikos nuosmukis suvienijo dvi socialines jègas, leidusias įsigalèti A. Lukašenkos režimui. Jos - tai senoji nomenklatūra, besipriešinanti rinkos ekonomikos reformoms, ir liumpenizuota bei labiausiai nuo nevykusių reformų nukentejjusi visuomenès dalis ${ }^{9}$.

\footnotetext{
${ }^{6}$ Plačiau apie grèsmių (nacionaliniam) saugumui specifikaciją žr.: B. Buzan Žmonès, valstybės ir baimè. Tarptautinio saugumo studijos po Šaltojo karo. - Vilnius: Eugrimas, 1997, p. 156-193.

${ }^{7}$ Prezeworski A., Alvarez M., Cheibub J.A., Limongi F. What Makes Democracy to Endure, Journal of Democracy, 1996. No. 7, p. 39-55.

${ }^{8}$ Davidonis R. The Challenge of Belarus, and European Responses, Institute for Security Studies, Occasional Papers., July 2001, No. 29, p. 5.

${ }^{9}$ Feduta A. „Sovetskije belorusy“: popytka opredelenija, Belarus Monitor, Minsk, 1999, s. 21-29.
} 
Beje, kalbant apie pastarają, pažymètina, kad didžiają Baltarusijos visuomenès dalį sudaro gyventojai, kurie gyvena kaimo vietovèse. O miestiečiai - patys neseniai atvykę iš provincijos ir besilaikantys patriarchalinių tradicinių vertybių. Baltarusių politologas Viktoras Černovas šių žmonių pasaulèžiūrą įvardija kaip archajinị konservatyvumą ir mitologinį mąstymą ${ }^{10}$. Tai - nedideli poreikiai, laisvès ir konkurencijos baime, ,,apsuptos tvirtovès“ psichologija, vienvaldystès siekimas, atstovaujamų institucijų reikšmės nesupratimas, orientacija ị autoritarinị charizmatinị lyderị, lojalumas bei kokios valdžios centrui, didelis prisitaikymo prie valdžios laipsnis, pasyvumas ir nuolaidumas. Štai kodèl Lukašenkos primesta autoritarizmo alternatyva ir Sajungos su Rusija (dažnai pateikiama Sovietų Sajungos restauravimo idejos kontekste) visiškai patenkina didesnès Baltarusijos gyventojų dalies lūkesčius. Negalima pamiršti, kad daugiau nei 30 procentų baltarusių turi Rusijoje artimų giminaičių. Daugelis baltarusių yra baigę rusiškąsias aukštąsias mokyklas, pradèję Rusijoje savo politinę ar profesinę karjerą, pagaliau kartu su rusais tarnavę armijoje ${ }^{11}$.

Tiesa, pabrežtina, kad jau išaugo ir ta karta, kuri nejaučia jokios nostalgijos nebeegzistuojančiai SSRS, turi pakankamai aukštą išsilavinimą, naudojasi internetu, pakankamai mobilūs ir aplankę įvairias Europos valstybes. Tačiau kartu akcentuotina, kad pasisakantys už šalies europietizaciją šios kartos atstovai, daugiausia gyvenantys Minske, netapatina savęs su opozicija ir net nelabai ja pasitiki. Tokị skeptiškumą daugiausia skatina tai, kad dabartinès opozicijos vadovai ir apskritai baltarusiškojo politinio elito branduolys vis dar naudoja tas politines ir visuomenines sąvokas, kurios buvo būdingos sovietiniam periodui ${ }^{12}$.

Tyrèjai, beje, kartais bando apeliuoti ị regioninę Baltarusijos diversifikaciją ir istorinès evoliucijos lemiamą šalies regionų specifiškumą (Vakarų Gudija, t.y. Gardino, Bresto sritys, Rytų Gudija, t.y. Vitebsko, Mogiliovo sritys). Tačiau iki šiol ginčijamasi, ar iš tikrujjų toks specifiškumas egzistuoja, o jei ir egzistuoja, ar tai yra veiksnys dabartineje Baltarusijos politineje raidoje?

Lukašenkos fenomenui atsirasti buvo palankūs ir kiti veiksniai. Paprastai aiškinama, kad Baltarusijoje nevyko ir politinès reformos. Nepriklausomybè nebuvo susijusi su tautinio judejjimo pakilimu šalyje. Skirtingai nei kaimyninèse šalyse, šis judejjimas nebuvo pagrindine jẻga, siekianti esminių pokyčių. Žinoma, didžia dalimi taip atsitiko todèl, kad sunku kalbèti apie baltarusių valstybingumo bei nacionalinio identiteto tradicijas.

Baltarusija ilgai buvo Lietuvos Didžiosios Kunigaikštystės bei Žečpospolitos dalis. Po to tapo Rusijos kolonija, pergyveno tris sukilimus, du pasaulinius karus, vos kelis mėnesius gyvavusią Baltarusijos Respubliką, bolševikų okupaciją, žiaurias Stalino represijas ir sovietinès Baltarusijos laikotarpị SSRS sudètyje. Negalima pamiršti, kad kelis amžius Maskva Baltarusijoje vykdè aktyvią rusifikavimo politiką. Tokie istorijos vingiai veikè baltarusių nacionalinę savimonę - ir valstybingumo tradicijos visuomenèje silpnos, ir nacionalinis identitetas menkai apibrèžtas.

\footnotetext{
${ }^{10}$ Chernov V. Priroda Politicheskogo Rezhima v Belarusii i Perspektivy Ego Transformaciji // Belarus-Monitor. Demokraticheskije Procesy v Belarosuji: Osnovnyje Tendenciji i Protivorechija., Minsk, 1997, s. 66-67.

${ }^{11}$ Zabytyj Sosed - Belarus v Kontekste rasširenija Evropejskogo Sojuza na Vostok. - Fundacja

Batorego, Warszawa, 2001, s. 7.

${ }^{12}$ Ibidem, s. 7-8.
} 
Beje, būtina pabrèžti, kad amžiaus pabaigoje oficialusis Minskas bandè kompensuoti nacionalinio identiteto problemas užsienio politikos priemonèmis. Konkrečiaiginčydamas Lietuvos teritorinį vientisumą. Pavyzdžiui, 1992 m. vasario mèn. 24 d. Baltarusijos Užsienio reikalų ministras Piotr Krauchanka atvirai pareiškẻ Europos Bendrijos delegacijai, kad Minskas abejoja, ar Vilnius teisétai priklauso Lietuvos Respublikai1 ${ }^{13}$.

Lukašenka panašių pareiškimų Lietuvos atžvilgiu nedarè, tačiau baltarusiškojo nacionalinio identiteto specifika šalies vidaus politikos rinkoje pasinaudojo. Dar amžiaus pabaigoje, pabrèždamas nepriklausomumą jokioms partijoms, jis pasirinko ir atitinkamą politinį moto: „Aš nei su dešiniaisiais, nei su kairiaisiais, aš - su liaudimi“. Plačiau vertinant, Lukašenka pasinaudojo labai silpnos partinès sistemos trūkumais. Vadinamosios demokratinès jëgos buvo susiskaldžiusios ir vadovaujamos lyderių, kurių formuojama politika stipriai nutolusi nuo Baltarusijos realybès. Kita vertus, iki 1995 m. Baltarusijoje dirbo dar sovietiniais laikais išrinktas parlamentas. Ši komunistų valdoma valdžios institucija blokavo opozicijos siūlymus surengti pirmalaikius rinkimus, ir reali valdžia atsidūrè vykdomosios valdžios rankose.

Pergalès vaisiais prezidentas naudojasi iki šiol. Dar prieš paskutinius prezidento rinkimus Baltarusijoje atliktos nepriklausomos sociologinès apklausos bylojo: jeigu rytoj vyktų rinkimai, prezidentu vèl būtų išrinktas Lukašenka. Jo atrama tebelieka kaimo gyventojai, degradavusi darbininkija, pensininkai bei vidaus reikalų kariuomenė. Šie visuomenès sluoksniai sudaro didžiają gyventojų dalį, kuriai priimtina dabartinè padètis ir kuri pasisako prieš radikalius pokyčius. Nors ir kalbama, kad didèja nepatenkintųju režimu ir baltarusiškos nomenklatūros gretose, pastaroji šiandien yra per silpna, kad sugebėtų suorganizuoti rūmų perversmą ir pašalinti Lukašenką iš valdžios. Opozicija irgi išlieka pakankamai silpna ir susiskaldžiusi. Ji taip ir nesugebèjo pasiūlyti nė vieno kandidato, kuris galètų sudaryti rimtesnę konkurenciją dabartiniam prezidentui.

Pasinaudojęs visomis aukščiau išvardintomis aplinkybėmis, kai kurių polito$\operatorname{logų~nuomone~}{ }^{14}$, Lukašenko sukūrè vadinamaji sultonistinị režimą, t.y. autoritarinio režimo sub-tipą, kuriame dominuoja iš esmès visose gyvenimo srityse personalizuotas valdymas, kuriame negalioja teisé, vyrauja žemas institucionalizacijos lygis, klientelizmas, klesti korupcija, neidentifikuojama aiški ideologija, išskyrus valdovo aukštinimą ir pan. Yra neblogai žinomi tokių režimų istoriniai pavyzdžiai: Duvalier režimas Haityje, Trujillo režimas Dominikos Respublikoje, Ceaushescu režimas Rumunijoje. Patirtis liudija, kad režimų pakeitimai tose istorinėse situacijose vyko su kraujo praliejimu, masinio ar karinio sukilimo pagalba.

Kalbant apie galimus scenarijus Baltarusijos atveju, kol kas nėra požymių, rodančių tokios alternatyvos perspektyvą. Problemiškiau yra su atsakymu ị klausimą, kokias pasekmes režimui atneštų vis blogejjanti ekonominè padètis ir net kai kurių ekspertų ižzvelgiami ekonominio kolapso požymiai. Kita vertus, gali atsiverti plačiau ir kai kurios kitos silpnesnès Lukašenkos režimo pusės - pavyzdžiui, prezidento legitimumas. Tačiau yra mažai abejojančių tuo, jog Baltarusijos raidą veiks vidaus ir išorinès veiksnių samplaika.

${ }^{13}$ Iš esmès Minsko rankomis komplikacijas Lietuvai kūrè Maskva. Klausimas buvo išspręstas 1995 m. Lietuvai ir Gudijai pasirašius Susitarimą dẻl sienų ir kiek vẻliau Draugystès ir kaimyninio bendradarbiavimo sutartị. Plačiau žr.: The Belarus Issue. Institute of International Relations and Political Science, Vilnius University, 2002, Working Papers, No. 1, p. 8.

${ }^{14}$ Ibidem. p. 13; Steven M. E., Taras K. Sultanism in Eastern Europe: The Socio-Political Roots of Authoritarian Populism in Belarus, Europe-Asia Studies, 2000,Vol. 52, No. 3, p. 523-547. 
Niekam nekyla abejonių, kad vienintelè jẻga, kurios paiso Minskas, yra Rusija. Niekas neabejoja ekonomine Baltarusijos priklausomybe nuo Rusijos. Kur kas mažiau akcentuojama, kad Rusijos veiksnį Lukašenka naudojo ir kaip savo politinio legitimumo šaltinį, tiek šalies viduje, tiek ignoruojant Vakarų nuomonę. Tačiau neseniai pasirode požymių, leidusių analitikams ir ekspertams prabilti apie laipsnišką šio šaltinio sekimą ${ }^{15}$.

\section{Baltarusijos-Rusijos santykiai: priklausomybès modelis teorijoje ir praktikoje}

Dar prieš trejetą metų buvo garsiai svarstomos Lukašenkos galimybės užimti aukščiausią Baltarusijos ir Rusijos sajungos postą. Prieš pusantrų metų prabilta apie tai, kad tik su Maskvos pagalba jis ir tegalįs išlaikyti valdžią Baltarusijoje. Šiandien Vladimiras Putinas kaltina Lukašenką, esą jis siekiąs Rusijos ir Baltarusijos sajungos pagalba atkurti Sovietų Sajungą ir darąs tai kenkdamas Rusijos valstybingumui.

Apskritai akivaizdu, kad po SSRS žlugimo Baltarusija niekada nebuvo nutraukusi savo ypač glaudžių ryšių su Rusija. Per visą laikotarpį po komunistinio režimo žlugimo išliko ypač stipri Baltarusijos politinè, ekonominè ir karinė priklausomybė nuo Rusijos. Dar 1993 m. gruodị Minskas pasirašè Nepriklausomų Valstybių Sandraugos Kolektyvinio saugumo sutartį. 1994 m. balandžio mėn. Baltarusija su Rusija pasirašè susitarimą dėl pinigų sajungos. $1996 \mathrm{~m}$. balandžio mèn. buvo pasirašytas susitarimas dėl Rusijos ir Baltarusijos sandraugos. 1997 m. gegužès mėn. Sutartis dèl Rusijos-Baltarusijos sajungos statutų. 1999 m. gruodžio 8 d. - Deklaracija dèl tolimesnès integracijos ir susitarimas apie sajunginès valstybès ịkūrimą. 2000 $\mathrm{m}$. lapkričio $30 \mathrm{~d}$. - Susitarimas dèl bendros sajunginès valstybès valiutos įvedimo. Šalia šių sutarčių atsirado visas pluoštas kitokio pobūdžio susitarimų ir sutarčių (per 100, iš jų apie 20 saugumo ir karinése srityse). Ir nors oficialiai kalbama apie dviejų šalių integraciją, be jokios abejonès, šiuo atveju veikia ne integraciniai, o priklausomybès modeliai. Ši priklausomybè leido Rusijai kontroliuoti, o dažnai ir kreipti tuos procesus, kurie vyksta Baltarusijos vidaus ir užsienio politikoje.

Priklausomybės modelis grindžiamas: etnonacionaliniu artumu, buvusiu Baltarusijos ekonomikos hyperintegruotumu ị sovietinę sistemą, ypač ị RSFSR; priklausomybe saugumo ir gynybos srityse ${ }^{16}$. Toks modelis leidžia Rusijai iš esmés manipuliuoti „Baltarusijos korta“, atsižvelgiant ị vidaus ir tarptautinę konsteliaciją. Pavyzdžiui, Boriso Jelcino laikais mainais ị geopolitinę sajungą Rusija paremdavo Lukašenkos režimą daugiau kaip $1 \mathrm{mlrd}$. JAV dolerių per metus. Pigiau parduodavo energijos išteklius, atverdavo savo rinką Baltarusijos prekėms, o daugiausiai leisdavo kaimyninès valstybės muitininkams pasilikti muitus už į vadinamają sajunginę valstybę (o išties ị Rusiją) vežamas prekes. Be to, pasinaudodamos muitų sajunga Baltarusijos prezidento administracijos sukurtos įmonès įvežè daug kontrabandinių prekių, kurios buvo parduotos Rusijoje. Boriso Jelcino laikais sajunga leido Rusijos elitui ịsivaizduoti, kad Rusija po SSRS žlugimo ne viską prarado ir išlieka galinga ir įtakinga valstybė. Be to, sajunga buvo priemonè stabdyti NATO plètrą į Rytus.

\footnotetext{
${ }^{15}$ Atskirkime muses nuo kotletų, Atgimimas, 2002 m. birželio 21-27, Nr. 24, p. 12.

${ }^{16}$ Wierzbowska-Miazga A. The Republic of Belarus or the Belarusian Republic ? Centre for Eastern Studies, Warsaw, 2001., p. 51-59.
} 
Putinui tapus Rusijos prezidentu, Lukašenkai teko palaidoti viltis ir svajones apie Rusijos valdymą iš dviejų valstybių sajungos viršūnès. Tuo metu didelẻ Rusijos rinkèjų dalis ilgejjosi stiprios rankos politikos, reveransų praeities simboliams, griežto tono bendraujant su Vakarais ir oligarchų itakos pažabojimo. Pastebėtina, kad siekdamas patraukti Rusijos piliečių dėmesi, Baltarusijos prezidentas savo kalbose tai akcentuodavo labiausiai. Putino prezidentavimo pradžia irgi rèmési tais principais. Palaipsniui Lukašenkai tapo sunku atrasti argumentų, kuriais jis būtų galèjęs iggyti Rusijos piliečių simpatijas. Prieš $2001 \mathrm{~m}$. rugsèjo 9 d. rinkimus jam norint išlikti valdžios olimpe teko įtikinėti Kremliaus lyderị, kad jis yra priimtiniausia kandidatūra.

Lukašenka laimėjo rinkimus. Demokratinè Vakarų bendrija nesutiko, kad tai buvo demokratiniai rinkimai ${ }^{17}$. Paradoksalu, tačiau tiesioginę Lukašenkos režimo kritiką užgožè kiti įvykiai - teroristų ataka prieš Jungtines Amerikos Valstijas.

Vis dèlto Minskui netrukus teko pajusti po 2001 m. rugsėjo 11 d. išryškèjusių pasaulinės politikos tendencijų poveiki. Pastaroji skleidèsi dviejuose lygmenyse: Baltarusijos-Rusijos bei tarptautinès saugumo bendruomenès - Baltarusijos santykių kontekstuose. Beje, reikia pripažinti, kad šiuos lygmenis gana greitai identifikavo ir pats Lukašenka.

Baltarusijos prezidentas, 2002 m. sausio pradžioje konkretizuodamas šalies užsienio politikos prioritetus, bandė stiprinti Baltarusijos ir Rusijos sajungą, ketinimą atkurti visaverčius santykius su Europos Sajunga ir pareiškè pasiryžimą plètoti lygiateisį dialogą su JAV daugeliu klausimų, tarp jų - kovojant su terorizmu ${ }^{18}$.

Tradiciškoms apeliacijoms ị sajunginès su Rusija valstybès kūrimą Lukašenka, regis, ši kartą turẻjo ir svarių įrodymų - ką tik Baltarusijai Maskvos skirtą antrają paskolos dalį - $30 \mathrm{mln}$. JAV dolerių sajunginès valstybès kūrimo išlaidoms finansuo$\mathrm{ti}^{19}$. Tačiau Minskas klydo, manydamas, kad sugeba prognozuoti Kremliaus veiksmus.

Iki šiol yra ginčijamasi, kokiais motyvais rèmėsi Putinas 2002 m. birželio mèn. susitikime su Lukašenka Sankt Peterburge leidęs suprasti, kad nepritaria Minsko siekiui suvienyti Rusiją ir Baltarusiją kaip lygiateisius subjektus. Veikiausiai motyvacija rėmėsi tiek Maskvos aktyviu įsitraukimu ị JAV suburtos antiteroristinės koalicijos gretas, Maskvos-Vašingtono santykių atšilimu, deklaruojamu provakarietiškos užsienio politikos kursu, tiek Baltarusijoje sudarytomis kliūtimis rusiškajam kapitalui dalyvauti planuojamame šalyje strateginių įmonių privatizacijos procese. Šiaip ar taip netrukus Rusijos prezidentas pareiške, kad Lukašenkai nepavyks atkurti Sovietų Sajungos.

Formaliai peno tokiai reakcijai suteikè Minsko parengtas Rusijos ir Baltarusijos sajungos konstitucijos projektas. Jame buvo numatoma, kad bus sukurta jungtinè valstybè, kurioje abi pusès turès lygias teises ir galimybę vetuoti bendrus sprendimus, o sajunginei valstybei vadovaus kas pusę metų besikeičiantys Rusijos ir Baltarusijos prezidentai. V. Putinui teko priminti, kas yra kas. Netgi nuskurdus Rusijai, jos ekonominė galia yra daugiau kaip 30 kartų didesnė nei Baltarusijos. Potekstė buvo daugiau nei aiški - Baltarusija turètų šlietis prie Rusijos ir tapti viena iš didžiosios valstybės provincijų, o ne svajoti apie poveikị Kremliuje. Ambicingoje Rusijos eko-

\footnotetext{
${ }^{17}$ Plačiau žr.: Manaev O. Prezidentskyje vybory: chto bylo na samom dele (Presidential Elections: What Happened in Reality), Analiticheskij Biuleten, Minsk, 2002, No. 1 (15)., s. 5-15.

${ }^{18}$ Lukašenka patvirtina ketinimą stiprinti Rusijos ir Baltarusijos sajungą, BNS, $2002 \mathrm{~m}$. sausio $14 \mathrm{~d}$.

${ }_{19}$ Rusija finansuoja bendras su Baltarusija valstybès kūrimo išlaidas, BNS, $2002 \mathrm{~m}$. sausio $4 \mathrm{~d}$.
} 
nomikos augimo programoje, skelbiančioje fiskalinị griežtumą ir liberalizmą, nėra vietos parazituojančiai Baltarusijos ekonomikai ${ }^{20}$.

Baltarusijos prezidentas atkirtį dave po gerokos pauzès. Reikia pripažinti, jog jo kalba Baltarusijos TV ekranuose nuskambejjo emocingai ir pakankamai griežtai Rusijos atžvilgiu. Jis dar kartą pabrěžè, kad dviejų valstybių sajunga turi būti kuriama lygiateisiais pagrindais, ir pareiškè, kad Baltarusija niekada netaps Rusijos Federacijos 90-uoju subjektu. Rugsėjo pradžioje Lukašenka dar kartą apkaltino Maskvą vilkinant planus dèl abiejų valstybių sajungos. „Aš visada buvau už sajungą, bet Maskva nori Baltarusiją ijungti ị Rusiją. Su tuo taikstytis neketinu“", - aiškino jis, pridūręs, kad Putino pasiūlymas dèl susijungimo (rugpjütị Kremlius pasiūlè surengti referendumą dèl abiejų valstybių susijungimo ir jei jo rezultatai būtų teigiami - rinkti vieną parlamentą bei prezidentą) įkvéptas noro ịtikti turtingiems rinkèjams ${ }^{21}$.

Pastebėtina, kad po šios kalbos Minskas sulaukẻ Kremliaus skambučio ${ }^{22}$. Panašu, kad ịtampa šiuo momentu sumažẻjo. Klausimas - ar ilgam?

Beveik niekas neabejoja, kad ne Baltarusijos ekonomika lemia Maskvos atsiribojimą nuo Minsko, ne sunkiai paties Putino slepiama asmeninè panieka Lukašenkai ar galų gale pastarojo vizijos sajunginès valstybės atžvilgiu, o neatsakytas klausimas dèl Lukašenkos veiksmų prognozuojamumo bei tarptautinès politikos konsteliacija ${ }^{23}$.

Vargu, ar atmestina nuomonè, kad Lukašenka gali tapti neprognozuojamu, jeigu pajaus realią asmeninę grèsmę iš Rusijos pusès ${ }^{24}$, t.y. jei kuriant realią Rusijos ir Baltarusijos sajungą, bus siekiama nušalinti ji nuo valdžios, o Baltarusiją de facto ijungti į Rusijos sudètį. Lukašenka desperatiškai bando išlikti valdžioje, neseniai pareiškęs, kad „,neatmeta galimybės dalyvauti prezidento rinkimuose 2006 m. ${ }^{\text {“25 }}$, t.y. neatmeta galimybės pakeisti Baltarusijos Respublikos Konstitucijos nuostatas, neleidžiančias siekti trečios kadencijos. Kitaip tariant, kilus grèsmei netekti valdžios, Lukašenka gali imtis neprognozuojamų veiksmų ir sukelti, pavyzdžiui, lokalaus masto karini konflikta.

Formalia tarptautinès konsteliacijos įtakos režimui išraiška tapo JAV Valstybės sekretoriaus Powello pokalbis su Rusijos užsienio reikalų ministru Igoriu Ivanovu ir tame pokalbyje iškeltas „Baltarusijos klausimas“ ESBO misijos likimo Minske kontekste. Tai dar kartą pabrěžè, kad praktiškai „Baltarusijos klausimas“ tarptautinėje Vakarų-Rytų santykių darbotvarkèje ypač tapo aktualiu po $2001 \mathrm{~m}$. rugsėjo 11 d., JAV inicijavus tarptautinę antiteroristinę koaliciją ir pradejjus ịgyvendinti naują NATORusijos bendradarbiavimo formulę.

\footnotetext{
${ }^{20}$ A. Norkus. Maskvos antausis Minskui, Lietuvos Rytas, 2002 m. birželio 22 d. Nr. 143.

${ }^{21}$ V. Putinui - Minsko kaltinimai, Lietuvos Rytas, 2002 m. rugsejo 9 d., Nr. 208.

${ }^{22}$ Sanko V. Kremliovskij nokdaun, Nezavisimaja Gazeta, 2002.09.04., Nr. 185.

${ }^{23}$ Kai kurie Rusijos politikai atvirai apkaltino Putiną, esą jo pasiūlymai Lukašenkai dèl dviejų valstybiu susijungimo pakurstyti JAV, Vokietijos ir kitų Vakarų sajungininkių. Plačiau žr.: Baltarusijos prezidentas gali netekti posto, Respublika, $2002 \mathrm{~m}$. rugpjūčio $16 \mathrm{~d}$.

${ }^{24}$ Šiame kontekste gali būti ịdomūs amerikiečių samprotavimai dèl diktatoriaus S. Huseino veiksmụ prognozuojamumo. Žr.: Whitelaw K., Mazetti M. Why War?, Cover Story, October 14, 2002.

${ }^{25}$ Konstitucija Lukašenkai ne kliūtis, Lietuvos Žinios, 2002 m. rugsejjo 19 d., Nr. 217; Žinių srautas. Minskas, Lietuvos Rytas, 2002 m. rugsejo 19 d., Nr. 217.
} 


\section{Tarptautinè saugumo bendrija ir Baltarusija}

Dar 2002 m. pradžioje Minskas galèjo pajusti naują tarptautinės saugumo bendrijos spaudimo režimui bangą. Jau sausio mèn. JAV, Izraelio, Lenkijos spaudoje pasirodė pranešimai apie neteisėtą Baltarusijos prekybą ginklais ${ }^{26}$. Vasario mèn. pradžioje Europos saugumo ir bendradarbiavimo organizacijos Parlamentinès Asamblejos (ESBO PA) specialios darbo grupès Baltarusijos klausimais vadovė Uta Kapf (Uta Capf) perspejjo, kad Baltarusijos ir Vakarų santykiuose gali „prasidėti ledynmetis, jeigu oficialusis Minskas nežengs žingsnių demokratizavimo linkme“"27. Vasario mẻn. viduryje JAV Kongreso atstovų rūmų delegacija po apsilankymo Minske pareiškẻ susirūpinimą dèl galimos Baltarusijos prekybos ginklais su terorizmą remiančiomis šalimis $^{28}$. Kovo pradžioje JAV pateikè Baltarusijai ultimatumą nutraukti karinės ginkluotès pardavimą terorizmą remiančioms šalims. JAV valstybės departamentas pareiškẻ, kad Amerika, siekdama užkirsti kelią tokiai veiklai, ketina imtis įvairių žygių - sankcijos yra viena iš tokių priemonių.

Kokias pasekmes šis pareiškimas ir apskritai jau senokai bręstantis JAVBaltarusijos konfliktas gali turèti Vakarų-Rytų santykiams apskritai? Nėra abejonės, šis klausimas svarbus ir Lietuvai.

Prisimintina, kad viena didžiausių pasaulinès įprastinių ginklų rinkos dalyvių Baltarusija laikoma jau nuo 1996 m. Ji patenka i pirmaji ginkluotès ir karinès technikos eksportuotojų dešimtuką. Gausius Baltarusijos karinio eksporto išteklius sąlygojo keletas veiksnių. Pirma, karinės pramonės gamybos sumažėjimas po SSRS žlugimo nebuvo toks žymus kaip Rusijoje. Antra, didžiają dalị įmonių tebekontroliuoja valstybè. Trečia, šalyje liko didelis naudotos rusiškosios karinės technikos arsenalas.

Dar 1994 m. Lukašenka nusprendè nevykdyti Sutarties dẻl ịprastinès ginkluotès Europoje ${ }^{29}$, arsenalo nenaikino, o pasiūlè ginklų užsienio klientams. Greta šio tipo eksporto Minskas gauna nemažą pelną iš pasaulinei rinkai tiekiamų ginkluotès ir amunicijos dalių gamybos. Prekyba ginklais Baltarusijai gyvybiškai svarbi finansiniu požiūriu. Kai kurių Vakarų ekspertų duomenimis, 1997-2000 m. šalis už prekybą ginkluote ir technika galejjo uždirbti apie vieną milijardą JAV dolerių. Manoma, kad per praëjusius metus Baltarusija tyliai tapo pagrindine karinės ginkluotès tiekëja radikaliam islamo pasauliui. Vien pernai palestiniečių kovotojams ir šalims, kurios teikia prieglobstị teroristams (Sirija, Iranas), Minskas slapta pardavẻ ginklų už daugiau kaip 500 milijonų JAV dolerių.

Baltarusijos įsitvirtinimas ginklų eksporto rinkoje ir vykdoma prekybos politika jau senokai kelia tarptautinės bendruomenès susirūpinimą. Pirmiausia šios šalies karinės pramonès veikla, ginklų prekybos sistema bei jos finansavimas yra labai

\footnotetext{
${ }^{26}$ Irodymų, kad Baltarusija neteisètai prekiauja ginklais „nèra ir negali būti“, teigia Baltarusijos URM, BNS, $2002 \mathrm{~m}$. vasario $7 \mathrm{~d}$.

${ }^{27}$ Baltarusijos ir Vakaru santykiuose gali prasidèti „ledynmetis“, mano ESBO PA grupès vadovė, BNS, $2002 \mathrm{~m}$. vasario $5 \mathrm{~d}$.

${ }^{28}$ JAV kongresmenai reiškia susirūpinimą dèl galimos Baltarusijos prekybos ginklais su terorizmą remiančiomis šalimis, $B N S, 2002 \mathrm{~m}$. vasario $17 \mathrm{~d}$.

${ }^{29} 1990 \mathrm{~m}$. tuometinès Europos Saugumo ir bendradarbiavimo konferencijos iniciatyva pasirašyta ir 1999 m. atnaujinta sutartis nustato leistinų penkių íprastinès ginkluotès tipų dislokavimo Europos regionuose skaičių, neviršijantị nustatytų ribų. Iš maždaug 30 valstybių, pasirašiusių adaptuotą sutarti, ją ratifikavo tik dvi - Baltarusija ir Ukraina.
} 
ịslaptinti. Tikètina, jog neviešinamų sandorių pelnas nusėda šešėliniame Lukašenkos biudžete. Antra, tai jau minèti Baltarusijos ginklų prekybos sandoriai su valstybemis, kurioms visuotinai taikomas Jungtinių tautų ginklų embargas. Pavyzdžiui, $2001 \mathrm{~m}$. spalio mẻn. lenkų žurnale „Wpróst“ pasirodė informacija, kad Minskas perdavinėja karinę technika teroristinėms grupuotėms Balkanuose, Pietų Amerikoje, Artimuosiuose Rytuose, ginklų siuntos „,nuséda“ Sudane ir net Afganistane.

Vašingtoną ypač neramina vis didejjantis Lukašenkos suinteresuotumas slaptu bendradarbiavimu su Iraku. Su Minsko ir Bagdado sandèriais priešlèktuvinès gynybos srityje yra aiškiai susiję kai kurie grèsmingi pokyčiai. $2002 \mathrm{~m}$. vasario mèn. JAV valstybès departamentas patvirtino, kad Irako priešlèktuvinès gynybos karininkai Baltarusijoje buvo slapta išmokyti naudotis naujausia priešlekktuvine raketų sistema S-300. Nuo balandžio pradžios tris kartus mėginta numušti JAV ir Didžiosios Britanijos léktuvus, patruliuojančius JT kontroliuojamoje neskraidymo zonoje. $2001 \mathrm{~m}$. tokių bandymų būta virš keturių šimtų. Dabar, kai S. Huseinas, protestuodamas prieš Izraelio karinius veiksmus Vakarų Krante, neskraidymo zonoje sutelkè priešlèktuvinès gynybos sistemas, G. V. Bušo administracijai panašu teks pripažinti, jog Baltarusijos karinè įranga bei kompetencija, kuria naudojasi Irakas, kelia pavojų amerikiečiams ir britams ${ }^{30}$.

Kai kurie ekspertai mano, kad nuo tokių veiksmų Minską atgrasintų ekonominės sankcijos, t.y. jos priverstų Baltarusiją stabdyti ar bent riboti nelegalų ginkluotès tiekimą į konfliktuojančias, keliančias grèsmę ar teroristines arabų valstybes. Neva būtų skaudžiai paliestas baltarusiškų metalurgijos gaminių bei trąšų eksportas, duodantis Baltarusijos biudžetui didžiausias užsienio valiutos ịplaukas. Tačiau reikia prisiminti, kad atsiribojusi nuo Vakarų ir vis dar Rusijos užnugarị jaučianti Baltarusija yra pakankamai atspari ekonominiam Vakarų spaudimui. Šiuo atveju verta kalbėti ne apie Vakarų investicijas Baltarusijoje, ar apie ES paramą, apsiribojančia humanitarine pagalba ir demokratizavimo programomis, o apie neginčijamą faktą, kad tik Rusijos stipriai palaikomas energetikos ūkis yra vienintelẻ priežastis, dèl kurios dar visiškai nežlugo Baltarusijos ekonomika ${ }^{31}$.

Politinès priemonès taip pat beveik iki galo panaudotos, nes Baltarusijos narystės įvairiose organizacijose sustabdymas bei ES valstybių-narių reiškiami protestai nedavẻ laukiamų rezultatų. Maža to, Minskas, grasindamas pasitraukti iš ESBO, iš esmès paralyžiavo ESBO misijos Baltarusijoje veiklą̧

Mesdamas iššǔkị Minskui, Vašingtonas rizikavo susidurti su Maskvos interesais. Net kelios prielaidos leidžia manyti, jog Rusija naudojasi kaimyninės Baltarusijos nelegalaus eksporto paslaugomis. Pirmiausia Maskvai, kuri nenori susikompromituoti tarptautinés bendrijos akyse, karinés prekybos srityje patogu naudotis Minsku ir taip išvengti tarptautinių draudimų ir apribojimų. Antra, turint omenyje Baltarusijos eksporto mastus, kyla abejonių, ar stambieji sandoriai vyksta be Rusijos paramos. Trečia, daugeliu atvejų Minskas neturi techninių galimybių iki galo sukomplek-

\footnotetext{
${ }^{30}$ A. Jankauskas. Ar JAV sustabdys ginkluotès tiekimą teroristams Europos pašonėje?, Lietuvos Rytas, $2002 \mathrm{~m}$. kovo $9 \mathrm{~d}$.

${ }^{31}$ Plačiau žr.: Lenzi M. - Op. cit.

${ }^{32}$ Baltarusijos ministras „nemato galimybès“ tęsti ESBO misijos veiklą, jei nebus pakeistas jos mandatas, BNS, 2002 m. sausio 13 d.; Konstitucija Lukašenkai ne kliūtis, Respublika, 2002 m. rugsejo 19., Nr. 217.
} 
tuoti ginkluotės sistemos. Ketvirta, apskritai pastaraisiais metais pastebimas vis glaudesnis Rusijos ir Baltarusijos karinis bendradarbiavimas (bendros karinès pratybos) ${ }^{33}$.

Taigi turint galvoje, kad Rusija ginklų eksporto versle gali turèti ne mažiau interesų nei Baltarusija, galima spèti, jos spręsti konfliktą su Minsku Vašingtonas gali bandyti tardamasis su Maskva. Kaip matėme, būtent šiame kontekste galime interpretuoti ir vykstantį Maskvos-Minsko santykių atšalimą.

Tad galima prognozuoti, kad, nerizikuodamos skelbiama strategine partneryste, JAV greičiausiai netaikys žadètų sankcijų Baltarusijai. Toks abipusis susitarimas būtų naudingas ir Rusijai, ir antiteroristinei koalicijai. Tuo tarpu Rusija ịgytų dar vieną kozirị ir sustiprintų savo įtaką pagalbos laukiančio Lukašenkos režimui. Be to, stiprèjant Rusijos įtakai Baltarusijoje, JAV galètų tikètis, jog daugiau tvarkos bus įvesta ginklų tiekimo labirintuose, kontroliuojamas jų patekimas ị politinių priešininkų rankas.

Kita vertus, karinio Irako klausimo sprendimo kontekste galima prognozuoti ir be kompromisinị Vašingtono požiūrị i oficialųji Minską. Tokią versiją patvirtintų JAV pozicija Ukrainos prezidento Leonido Kučmos, ittariamu 2000 m. sankcionavus ginkluotės pardavimą Huseinui, atžvilgiu. Lukašenkos atveju beliktų prisiminti ne tiek Baltarusijoje vykusius Irako priešlèktuvinès gynybos karininkų apmokymus, kiek kur kas rimtesnę strateginès Irako grèsmès tarptautinei bendrijai istoriją - 1995 m., tiesiogiai pažeidžiant Jungtinių Tautų sankcijas Bagdadui, Minskas pardavė Huseino režimui specialią įrangą su deimantiniais antgaliais, naudojamais tam tikrų branduolinio ginklo sudètinių dalių gamyboje ${ }^{34}$.

Tiesa, galima ir pesimistine JAV-Baltarusijos santykiu įtampos atomazga. Vakarų spaudimo priemonių igyvendinimas gali sustiprinti antivakarietiškas nuotaikas šalyje bei suteikti paramą autoritariniam režimui. Be to, tiesioginėje akistatoje su griežtai nusiteikusiomis JAV Lukašenka gali tapti sunkiai prognozuojamas. Niekas negalètų paneigti, jog jis gali atsiriboti nuo Kremliaus, imtis nenuspejjamų, spontaniškų veiksmų, keliančių destabilizacijos grèsmę kitoms regiono valstybėms, taip pat ir NATO narystei besirengiančiai Lietuvai.

\section{Lietuvos-Baltarusijos santykiai}

Lietuvos-Baltarusijos santykių raida skirstytina į kelis etapus: 1990-1992 m., 1992-1995 m., nuo 1996-97 m. Pirmojo etapo dinamiką apsprendè dvišalių Vilniaus-Maskvos ir Minsko-Maskvos santykių specifiškumas. Antrajji - Maskvos veiktas Minsko politinis kursas skatinti separatizmą Lietuvoje ${ }^{35}$. Trečiaji - charakterizavo bandymai grịsti santykius geros kaimynystès principais, vadovaujantis $1995 \mathrm{~m}$. vasario 6 d. sutartimi „Dèl geros kaimynystès ir bendradarbiavimo“, ir išryškèję geopolitinès gravitacijos skirtumai.

Būtent pastarieji privertè traktuoti Baltarusijos kaimynystę Lietuvai kaip ypač nepalankią politinių, karinių, socialinių, ekonominių grẻsmių kontekste.

Pirmiausia, autoritarinio režimo Baltarusijoje egzistavimas kelia grèsmę per

\footnotetext{
${ }^{33}$ Jankauskas A. - Op. cit. Beje, nemaža dalis bendru pratybų vyksta Rusijos Federacijos Kaliningrado srityje.

${ }^{34}$ Lenzi M. - Op. cit.

${ }^{35}$ Lopata R. (ed.) National Question in Lithuania // www.nato.inf/acad/fellow/96-98/lopata.polf
} 
se visam regionui dèl galimo režimo neprognozuojamumo, o taip pat dẻl neaiškių Baltarusijos-Rusijos sajungos kūrimo pasekmių.

Neabejotina, kad Baltarusija yra labiausiai militarizuota teritorija Lietuvos geostrategineje erdvejje ${ }^{36}$. Baltarusijoje sutelktas didelis karinès puolamosios ginkluotès kiekis ir gausus karinis potencialas ${ }^{37}$, o tai - potencialus karinès grèsmės šaltinis. I ji kreipiamas dẻmesys ne tik dẻl minètų baltarusių vykdytų karinių pratybų pobūdžio, bet ir dèl abejonių, ar Minskas de facto visada laikytųsi tarptautinès teisės normų?

Lietuvos stojimo į Europos Sajungą ir Šengeno sistemą kontekste pabrěžtina, kad absoliuti dauguma nelegalių migrantų i Lietuvą patenka iš Baltarusijos, kuri iki šiol nèra demarkavusi valstybinès sienos su Lietuva. Neatmestina galimybè, kad žymiai pablogejjus ekonominei padèčiai Baltarusijoje, galimi ne tik didelio masto socialiniai neramumai šios šalies viduje, bet ir masinė baltarusių migracija iš šalies.

Pagaliau ekonominių Lietuvos ir Baltarusijos saitų veiksnys. Nors ekonominè Vilniaus ir Minsko tarpusavio priklausomybė yra gana maža, tačiau grèsmės Lietuvos energetikos sektoriui yra akivaizdžios ${ }^{39}$.

Be to, Lietuva aiškiai suvokia ir ekologiniu grẻsmių pasekmes, kylančias kaimyninėje valstybèje. Dél ekonominių sunkumų Baltarusija nèra pajẻgi ne tik užtikrinti tinkamą veikiančiu įmonių ekologinę priežiūrą, bet ir susiduria su sunkumais utilizuojant dar nuo SSRS laikų išlikusius šaudmenis ${ }^{40}$.

Lietuva, siekianti narystės euroatlantinėse institucijose, neutralizuoti minètas grèsmes ir kartu užsitikrinti aktyvios Baltijos Rytinio ir Rytų Europos subregionų veikèjos statusą siūlè tarptautinei bendruomenei praktiškai įgyvendinti įvairius galimų santykių su Baltarusija variantus („,tiltas“, „tarpininke்“, „eksperte்“). Vilnius viešai deklaravo, kad šių variantų igyvendinimą apsprendžia ne tik aiškiai identifikuotas grèsmių pobūdis, bet ir:

- Lietuvos pozicijos Baltarusijos atžvilgiu derinimas su sajungininku Vakaruose pozicija, aktyviai prisijungiant prie euroatlantinės bendrijos pareiškimų dẻl Baltarusijos, kuriais skatinama demokratijos plètra šalyje ir nustatomi kriterijai santykių normalizavimui, ir raginant oficialujị Minską atkreipti dèmesị i šias rekomendacijas, ir imtis konkrečių veiksmų, garantuojančių šalies demokratinį vystymąsi ir santykių su tarptautine bendrija sureguliavimą;

- Lietuvos nesuinteresuotumas tarptautine Baltarusijos izoliacija, kuri gali neigiamai veikti šios šalies demokratizaciją, jos santykių normalizavimą su Vakarų šalimis ir tuo pačiu Europos bei regiono stabilumą bei saugumą.

\footnotetext{
${ }^{36}$ Lietuvos karinès gynybos strategija.,Vilnius, 2000., p. 3, 7-8.

${ }^{37}$ Nurodoma, kad Baltarusija disponuoja 1800 tankais, 2500 šarvuočiais, 60 karinių sraigtasparnių, 250 karinių lèktuvų ir apie 85000 karių. Plačiau žr.: SIPRI Yearbok 2002: Armaments, Disarmament and International Security, Oxford University Press, 2002; The Military Balance 2000-2001, London, Oxford University Press, 2000. p. 87.

${ }^{38}$ Baltarusijos karinejje doktrinoje yra deklaruojama dauguma visuotinai pripažintų tarptautinès teisès normų, tačiau nèra aiškiai ịtvirtintas pats tarptautinès teisès nuostatų laikymosi principas. Šiame kontekste ypač iškalbingais yra Lukašenkos ir Huseino karinio bendradarbiavimo faktai.

${ }^{39}$ Čia turima galvoje ne tik tai, kad iš Rusijos ị Lietuvą einančio dujotiekio čiaupas ir skaitikliai yra Baltarusijos teritorijoje, bet ir tai, kad nèra aišku, kokios gali būti Lukašenkos bandymų aktyviai naudoti energetikos sektoriu santykiuose su Rusija pasekmès Lietuvos ūkiui.

${ }^{40}$ Baltarusijos kariškiams iškilo šaudmenų utilizavimo problema, $B N S, 2002 \mathrm{~m}$. spalio $2 \mathrm{~d}$.
} 
Šie motyvai, o taip pat praktinè santykių su Baltarusija patirtis apsprende ir konkrečią Vilniaus poziciją Minsko atžvilgiu - vykdyti pragmatiško selektyvaus bendradarbiavimo politiką $a^{41}$. Praktikoje ji reiškia, kad politinis bendradarbiavimas su Baltarusija turètų būti minimalus (pavyzdžiui, oficialių valstybès vadovų bei aukšto rango pareigūnų vizitai nevyksta nuo $2000 \mathrm{~m}$. pabaigos), kartu palaikant ryšius su atskiromis Baltarusijos valdžios struktūromis ir plètojant dvišalį bendradarbiavimą tose srityse, kurie yra svarbūs ne tik Lietuvos, bet ir viso regiono saugumui bei stabilumui (valstybinių sienos demarkavimas, nelegali migracija, regionų bendradarbiavimas, energetikos klausimai, etc.), nepaisant Baltarusijos politinès raidos krypties.

Būtent šią politinę liniją santykiuose su Baltarusija $2002 \mathrm{~m}$. pirmajame pusmetyje Lietuva, pirmininkaudama Europos Tarybai, bandė akcentuoti. Nepaisant teigiamų vertinimų ${ }^{42}$, tokios linijos perspektyvumas tebelieka miglotas, kadangi tarptautinés saugumo bendrijos politikoje Baltarusijos atžvilgiu iki šiol vyrauja tam tikras miglotumas galimų prioritetų atžvilgiu ${ }^{43}$.

\section{Išvados}

Baltarusija yra labiausiai autoritariška valstybė Vidurio ir Vidurio Rytų Europoje. Aleksandro Lukašenkos režimo keliamas grèsmes tarptautinè saugumo bendrija identifikuoja globaliniame ir regioniniame lygmenyse. Sios grèsmès kyla ne tik dèl autoritarinio režimo egzistavimo Baltarusijoje per se, bet ir dèl šio režimo neprognozuojamumo vidaus ir užsienio politikoje.

Būtent Lukašenkos režimo neprognozuojamumas vidaus ir užsienio politikos sferose, politinis spontaniškumas, galimas karinio sektoriaus panaudojimas režimo legitimacijai, ekonominio žlugimo grèsmè, socialinių pasekmių nevaldomumas kelia ypač apčiuopiamas grèsmes Lietuvai.

Kai yra tokia padètis, Vilniaus diegiama pragmatiško selektyvaus bendradarbiavimo taktika gali būti sékminga tik tarptautinei saugumo bendrijai turint realius ittakos Lukašenkos režimo evoliucijai svertus.

\footnotetext{
${ }^{41}$ Lithuania's Relations with Belarus and Internal situation in Belarus, Druskininkai, 2002, p. 1-6. ${ }^{42}$ Lietuvos ministras Strasbūre pristate ET pirmininkavimo prioritetus, BNS, $2002 \mathrm{~m}$. sausio $22 \mathrm{~d}$.

${ }^{43}$ VU Tarptautinių santykių ir politikos mokslų instituto surengto apskrito stalo diskusijos „Bendradarbiavimas su Baltarusija: patirtis ir perspektyvos“ medžiaga, Druskininkai, 2002 m. kovo 1-3 d.
} 